RISMED 00140

\title{
European Teratology Society 20th Annual Conference
}

\author{
Würzburg, Germany \\ 31 August-3 September, 1992
}

The European Teratology Society and the Local Organizing Committee are pleased to announce that the 20th ETS Conference will be held at the Congress Center and Hotel Maritim, on the banks of the Main, close to the centre of Würzburg, Germany, from August 31 to September 3, 1992.

The conference will include symposia on:

I. Chemical structure and teratogenicity

II. Harmonization of guidelines: an update

III. Embryonic nutrition and development

Discussion groups will include: Molecular developmental biology and human teratology; Classification systems in reproductive toxicology; Terminology in teratology; Teratology and clinical diagnosis; Occupation, nutrition and malformation.

There will be a keynote lecture on progress in teratology over 20 years, and an international round-table discussion on the future of teratology and of the societies.

There will be a satellite symposium on neurobehavioural teratology.

Free communications, either platform or poster, are invited on all aspects of teratology.

\section{Further information from:}

Geert Prins MD, Secretary ETS, PO Box 36, 4493 AG Kamperland, The Netherlands. Fax: 31-1107-1860, or Dr. med. vet. Christian Baeder, President Local Organizing Committee, Toxicology, Hoechst AG, Mainzer Landstrasse 500, D 6233 Hattersheim/Main, Germany. Fax: 49-6190-2706. 